\title{
Efficacy of a Novel Whey Protein Gel Complex to Increase the Unsaturated Fatty Acid Composition of Bovine Milk Fat
}

\author{
S. M. Carroll,, ${ }^{*}$ E. J. DePeters, ${ }^{\star 1}$ and M. Rosenberg† \\ *Department of Animal Science, and \\ †Department of Food Science, University of California, Davis 95616
}

\begin{abstract}
A novel whey protein emulsion gel (WPEG) complex was developed to protect dietary unsaturated fatty acids from rumen biohydrogenation with the goal of modifying the fatty acid composition of milk fat. Three experiments were conducted with WPEG complexes made from either whey protein concentrate containing $80 \%$ crude protein, whey protein isolate, or whey protein concentrate high-gel capacity. Each experiment lasted $3 \mathrm{wk}$. All cows received a basal total mixed ration (TMR). During wk 1 and 3, all cows received only the TMR. During wk 2, 3 control cows received $330 \mathrm{~g} / \mathrm{d}$ of soybean oil added to the TMR, and the other 3 cows received $330 \mathrm{~g} / \mathrm{d}$ of soybean oil in one of the WPEG complexes. During wk 2, C18:2 increased from 3.29 to $5.88 \mathrm{~g} / 100 \mathrm{~g}$ of fat in Experiment 1, 2.91 to $7.42 \mathrm{~g} / 100$ $\mathrm{g}$ of fat in Experiment 2, and 3.57 to $6.56 \mathrm{~g} / 100 \mathrm{~g}$ of fat in Experiment 3 for WPEG cows. Fatty acid C18:3 increased from 0.51 to $0.84,0.52$ to 1.15 , and 0.51 to $0.97 \mathrm{~g} / 100 \mathrm{~g}$ of fat for Experiments 1, 2, and 3, respectively, for WPEG cows. Higher proportions of C18:1 trans-9 in milk fat of control cows compared with WPEG cows were seen in all experiments. The proportion of C18:1 trans-11 was also higher in control cows in Experiments 1 and 2, but not in Experiment 3. The WPEG complexes successfully protected unsaturated fatty acids from rumen biohydrogenation and resulted in an increase in the unsaturated fatty acid composition of milk fat produced by Holstein cows without increasing the trans 18-carbon monoenes.
\end{abstract}

Key words: whey protein, rumen biohydrogenation, fatty acid, milk fatty acid composition

\section{INTRODUCTION}

Milk and dairy products contribute a substantial proportion of the fat, especially saturated lipids, in the Western diet (Gregory et al., 1990; German et al., 1997;

Received July 1, 2005.

Accepted October 4, 2005.

${ }^{1}$ Corresponding author: ejdepeters@ucdavis.edu
Havel, 1997; Barker, 2000; Kromhout et al., 2002). Intake of saturated fatty acids has been strongly implicated in the etiology of coronary heart disease (LaRosa et al., 1990), currently the leading cause of death in the United States. Given the importance of dairy products in the US diet, an increase in the proportion of unsaturated fatty acids in milk fat would constitute a major improvement of the dietary value of milk, and result in a substantial improvement of the overall quality of the human diet.

Two strategies to achieve modification of ruminant milk fat are currently being pursued worldwide. Attempts to directly modify the milk fat metabolome have achieved limited success (Creamer et al., 2002; Reh et al., 2004). However, direct genomic modification is not a flexible approach; changes in the metabolome are permanent. In contrast, dietary regimens of dairy cows that attempt to increase the proportion of desirable fatty acids (FA) in the milk fat matrix have been successful to varying degrees (Hodges et al., 1975; Ashes et al., 1997, 2000). Advantages of the nutritional approach include its inherent flexibility, lack of governmental regulatory implications, and low consumer resistance.

Emulsification of vegetable oils with protein and its subsequent treatment of the mixture with formaldehyde produced a matrix that reduced rumen biohydrogenation of unsaturated FA (Scott et al., 1971). Formaldehyde-based feed additives for dairy cows were shown to increase the proportion of linoleic acid (C18:2) in milk fat (Pan et al., 1972; Wrenn et al., 1976), as well as the proportion of unsaturated to saturated FA. Positive effects on fat metabolism of humans (e.g., lower plasma cholesterol) consuming dairy and meat products from cattle fed these rumen-protected lipids have been clearly documented (Hodges et al., 1975; Noakes et al., 1996). However, use of formaldehyde-based products to alter milk FA has not been commercially feasible in the United States because of regulatory prohibition of feeding formaldehyde to cattle.

Heat-induced gelation of whey protein has not yet been studied as a method to protect unsaturated lipids from rumen biohydrogenation. The process involves sequential events that include unfolding and reorganization of surface structures of the protein molecules, expo- 
Table 1. Composition of the different whey protein emulsion gel protein sources on a wet basis

\begin{tabular}{lccc}
\hline & \multicolumn{3}{c}{ Protein source $^{1}$} \\
\cline { 2 - 4 } Composition & WPC80 & WPI & WPCHG \\
\cline { 2 - 4 } & & $\%$ & \\
Moisture & 4.0 & 5.0 & 4.2 \\
Lactose & 4.4 & 0.0 & 4.0 \\
Lipids & 4.7 & 0.3 & 4.9 \\
Protein & 82.3 & 95.0 & 82.3 \\
Ash & 2.8 & 2.0 & 4.2 \\
\hline
\end{tabular}

${ }^{1}$ WPC80 $=80 \%$ Whey protein concentrate (Proliant 8000, Hilmar Cheese Co., Hilmar, CA), Experiment 1; WPI = whey protein isolate, (BiPRO, Davisco Foods Int., Inc., Eden Prairie, MN) Experiment 2; WPCHG $=$ high gel whey protein concentrate (Proliant 8200, Hilmar Cheese Co.), Experiment 3.

sure of hydrophobic groups, and activation of sulfhydryl groups (Morr and Ha, 1993; Gezimati et al., 1996; Tolstoguzov, 1996; Verheul and Roefs, 1998a,b; Ikeda et al., 2001). These events are followed by the formation of protein aggregates that interact with each other to form a three-dimensional protein network of the whey protein gels.

Thus, our objective was to determine the efficacy of various, novel dietary whey protein emulsion gel (WPEG) complexes to protect unsaturated FA from rumen biohydrogenation and increase the unsaturated FA composition of milk fat of Holstein cows.

\section{MATERIALS AND METHODS}

\section{Cows, Experimental Design, and Diets}

Initially, one WPEG formulation was developed. However, as this research progressed, 2 additional WPEG products were formulated and tested. Thus, 3 experiments were conducted to test 3 uniquely formulated WPEG complexes. The WPEG is based upon the formation of disulfide bonds between the proteins, an event that occurs during heat-induced gelation of whey proteins (Morr and Ha, 1993). These protein-protein interactions lead to permanent cross-links within the protein network (Chen and Dickinson, 1999). The 3 protein sources used in the WPEG complexes included whey protein concentrate containing 80\% CP (Experiment 1), whey protein isolate (Experiment 2), or whey protein concentrate with high gel capacity properties associated with its mineral composition (Experiment 3; Table 1). The whey protein isolate-based WPEG (WPI; BiPRO, Davisco Foods Int., Inc., Eden Prairie, MN) is dependent upon protein-protein interactions as a result of the $\beta$-lactoglobulin component of whey protein. In contrast, whey protein concentrate contains both protein and lactose. Therefore, the whey protein $80 \% \mathrm{CP}$ based WPEG (WPC80; Proliant 8000, Hilmar Cheese
Table 2. Fatty acid (FA) composition of soybean oil

\begin{tabular}{lc}
\hline Fatty acid & $\mathrm{g} / 100 \mathrm{~g}$ \\
of $\mathrm{FA}$
\end{tabular}

Co., Hilmar, CA) involves the chemistry of proteinprotein interactions similar to WPI but also involves interactions between amino acids and a reducing sugar (Maillard reaction). Use of whey protein concentrate with high gel capacity (WPCHG; Proliant 8200, Hilmar Cheese Co.) involves similar protein-protein interactions in addition to Maillard reactions between amino acids and a reducing sugar. Soybean oil was chosen as the lipid source for each product because of its relatively high concentration of polyunsaturated FA (PUFA), in particular linoleic acid (Table 2). Changes in the C18:2 content of milk fat were used to indicate the degree of protection of unsaturated FA from ruminal biohydrogenation. The method associated with WPEG formulation is described in patent applications (Rosenberg and DePeters, 2004, 2005).

Each experiment used 4 primiparous and 2 multiparous Holstein cows averaging $116 \pm 14 \mathrm{~d}$ in milk at the start of this study. Cows, which were not the same in each study, were housed at the Dairy Teaching and Research Facility at the University of California (Davis) in a shared concrete pen with sand-bedded freestalls. Each cow received $500 \mathrm{mg}$ of exogenous recombinant bST (Posilac, Monsanto Co., St. Louis, MO) once every $14 \mathrm{~d}$ for the duration of the study. The Animal Use and Care Administrative Committee of the University of California at Davis approved care of the cows.

The experimental plan was similar for all experiments, which were each 3 wk in duration. All cows were fed the same TMR for all 3 wk (Table 3). During wk 1 and 3 , all cows received only the TMR but, during wk 2,3 of the 6 cows received approximately $550 \mathrm{~g}$ of one of the WPEG (equivalent to approximately $165 \mathrm{~g}$ of oil) hand-mixed into their TMR at each feeding. The 3 remaining (control) cows received the unprocessed ingredients of the respective WPEG hand-mixed into their TMR. Wheat mill-run (115 g/feeding) was handmixed with the soybean oil within a plastic bag and used as a carrier for the soybean oil fed to control cows, but wheat mill-run was also added to the TMR of WPEG cows so that all dietary ingredients were identical for both groups of cows. Thus, the treatment variable was 
Table 3. Ingredient and chemical composition of the basal TMR on a DM basis

\begin{tabular}{lr}
\hline Ingredient & $\%$ \\
\hline Alfalfa hay, sliced & 42.0 \\
Beet pulp, dehydrated/shredded & 14.0 \\
Corn grain, steam flaked & 10.0 \\
Barley grain, steam rolled & 10.0 \\
Cottonseed, whole linted & 10.0 \\
Molasses, liquid/cane & 5.0 \\
Almond hulls & 4.0 \\
Soybean meal, 48\% CP solvent & 3.0 \\
Mineral premix 1 & 2.0 \\
Chemical composition & \\
CP & 17.87 \\
Ether extract & 2.71 \\
ADF & 24.22 \\
NDF & 35.87 \\
Ash & 8.49 \\
Ca & 1.34 \\
Na & 0.24 \\
Mg & 0.40 \\
$\mathrm{Zn}$ & 0.04 \\
\hline
\end{tabular}

${ }^{1}$ Mineral premix contains: 8.03 to $10.23 \% \mathrm{Ca}$, not more than $12.01 \%$ $\mathrm{Na}$ not less than $4 \% \mathrm{P}, 16.15$ to $17 \mathrm{ppm}$ Se, and $444.6 \mathrm{mg}$ of Rabon/ kg. Nutrius Bioproducts, Inc., Kingsburg, CA.

the protection of the soybean oil from rumen biohydrogenation by the WPEG. Initial observation during addition of the wheat mill-run/soybean oil mixture to the TMR from the plastic bags indicated that some oil remained on the surface of the bags. Bags were subsequently turned inside out and rubbed onto the TMR to include as much of the mixture as possible in the diet. Oil and wheat mill-run were enclosed in dark, plastic containers, and stored in a $10^{\circ} \mathrm{C}$ refrigerator.

It is important to note that the experimental design was limited due to inadequate capacity of the available equipment to produce quantities of WPEG sufficient for prolonged feeding and testing.

Cows were fed individually via Calan electronic gates (American Calan Inc., Northwood, NH) twice a day at approximately 0730 and $1930 \mathrm{~h}$ following milking. Cows had unlimited access to water. Feed refusals were weighed and recorded before the a.m. feeding. Milk weights were measured and sampled from each cow at each milking using Westfalia milk meters and samplers (Westfalia, Naperville, IL). Milk samples were preserved with 2-bromo-2-nitro-propane-1,3 diol (Silliker Laboratories, Inc., Modesto, CA) and stored at $5^{\circ} \mathrm{C}$ until analysis, which was conducted within $14 \mathrm{~h}$ of collection. Individual a.m. and p.m. milk samples were analyzed for chemical composition.

Diet and feed refusals were sampled daily and composited by week. A subsample was weighed and dried in a $100^{\circ} \mathrm{C}$ forced-air oven for approximately $16 \mathrm{~h}$ for $\mathrm{DM}$ determination. The remainder of each sample was air-dried at room temperature $\left(25^{\circ} \mathrm{C}\right)$ for approximately
$120 \mathrm{~h}$ and subsampled. Subsamples were ground in a Wiley mill (Arthur A. Thomas, Philadelphia, PA) to pass a 1-mm screen, and the ground samples were stored at room temperature in a sealed plastic container for chemical analysis.

Blood samples were collected into EDTA $\left(\mathrm{K}_{3}\right)$ vacutainers by venipuncture of the tail vein $2 \mathrm{~h}$ after a.m. feedings on $\mathrm{d} 12$ of each experiment. Plasma was stored at $-20^{\circ} \mathrm{C}$ prior to analysis of $\mathrm{FA}$.

\section{WPEG Formulation}

The protein source (WPC80, WPI, or WPCHG) was dissolved in tap water to create an approximately $17 \%$ (wt/wt) protein solution at $40^{\circ} \mathrm{C}$ (Rosenberg and DePeters, 2004, 2005). The resulting mixture was stirred using a Servodyne mixer equipped with a model 5000020 mixer head (Cole-Parmer Instrument Co., Chicago, IL) at $500 \mathrm{rpm}$ until completely dissolved. Each solution was stored at $4^{\circ} \mathrm{C}$ for $10 \mathrm{~h}$, after which the temperature was adjusted to $25^{\circ} \mathrm{C}$ and the soybean oil added as a lipid filler phase (to yield approximately a $30 \%$ fat final product on a wet basis) as the solution was stirred in a stainless steel bucket at 8,000 rpm using a model L4RT Silverson mixer (Silverson Machines Inc., East Longmeadow, MA) equipped with an emulsion screen. After addition of the soybean oil, the mixture was allowed to stir for an additional $2 \mathrm{~min}$ at 8,000 rpm to yield a coarse emulsion. The emulsion was then homogenized using a 2-stage high-pressure homogenizer (Type 15M 8TBL Gaulin Homogenizer, Gaulin Co. Inc., Wilmington, MA) 3 times to yield a fine final emulsion. Particle size was determined using a Malvern MasterSizer MS20 (Malvern, Worcester, UK). The final emulsion was placed into cans (\#408 cans, $11.4 \mathrm{~cm}$ height, 10.2 $\mathrm{cm}$ diameter) and sealed under a vacuum using a Type 23-OS-4 Vacuum Closing Machine (Continental Can Co., New York, NY). The sealed cans were then placed in a FMC Steritort (FMC Corporation, San Jose, CA) and heat-treated at $120^{\circ} \mathrm{C}$ for $138 \mathrm{~min}$. Following heat treatment, the cans were cooled in a water bath to approximately 25 to $27^{\circ} \mathrm{C}$ and stored at that temperature. Final consistency of the product was a semisolid gel, which was cut by hand into approximately $1.3-\mathrm{cm}$ pieces to be fed to WPEG cows.

\section{Analytical Procedures}

Feed samples were analyzed for DM (AOAC, 1990; method \#925.40), OM (AOAC, 1990; method \#967.05), total nitrogen (AOAC, 1990; method \#984.13), ether extract (AOAC, 1990; method \#920.39), and ash (AOAC, 1990; method \#923.03). Feed was also analyzed for NDF (Van Soest et al., 1991), ADF, cellulose, and lignin (Rob- 
ertson and Van Soest, 1981). Feed refusal samples were analyzed for DM, N, ether extract, ash, NDF, and ADF as described.

Fat, protein, lactose, and SNF determinations of individual a.m. and p.m. milk samples from each cow were performed using an infrared analyzer (AOAC, 1990; method \#990.20) within $14 \mathrm{~h}$ of collection. During this time, 10-mL aliquots were transferred into test tubes for FA analysis. Fat from milk was extracted and triacylglycerol FA composition determined according to methods described previously (Crocker et al., 1998; DePeters et al., 2001). Briefly, methyl esters of FA were separated and quantified by GLC (model 5890; flameionization detector and model 7673A auto injector, Hewlett-Packard, Palo Alto, CA) using a fused silica capillary column (SP-2560, $100 \mathrm{~m} \times 0.25 \mathrm{~mm}$; Supelco Inc., Bellefonte, PA). The carrier used was hydrogen gas with $0.77 \mathrm{~mL} / \mathrm{min}$ flow rate, $220^{\circ} \mathrm{C}$ injector temperature, 1:88 split ratio, and constant column temperature of $175^{\circ} \mathrm{C}$. Fatty acid peaks were identified and quantified by comparison with a standard mixture containing known levels of FA.

Fatty acid composition of the WPEG products was determined according to Sukhija and Palmquist (1990), but using hexane instead of benzene. Plasma FA were extracted according to Ingalls et al. (1995), plated, and scraped; the silica gel containing the lipid was methylated with acetyl chloride in methanol, and the FA identified by GLC according to Nakamura et al. (1992).

\section{Data and Statistical Analyses}

Milk composition and milk FA data during the second week of each experiment were used beginning at the sixth milking after initial WPEG feeding and ending after the last WPEG feeding to provide time for stabilization of milk constituents. It was decided to begin analyses during the sixth milking after reviewing data and determining that stabilization generally occurred approximately $79 \mathrm{~h}$ after the start of WPEG feeding.

Comparisons were made between control and WPEG milk constituents, milk FA, and plasma FA data using the Student's $t$-test procedure of SAS (SAS Institute, 1985), with treatment as the class and $P \leq 0.05$ accepted as significant.

Comparisons of treatment week FA proportions with nontreatment weeks (wk 2 vs. wk 1 ) during each experiment were done using the GLM procedure of SAS (1985) with an appropriate contrast statement. The following model was used:

$$
\mathrm{Y}_{\mathrm{ij}}=\mu+\mathrm{T}_{\mathrm{i}}+\mathrm{E}_{\mathrm{ij}}
$$

where $\mu=$ mean; $\mathrm{T}_{\mathrm{i}}=$ treatment, $\mathrm{i}=1,2$; and $\mathrm{E}_{\mathrm{ij}}=$ residual error.
Efficiency of transfer of FA from soybean oil to milk fat was calculated as: (daily milk FA production of WPEG cows - daily milk FA production of control cows)/ FA intake from oil.

Data from wk 3 were not statistically analyzed, but presented in figures for information only. Each experiment was performed successively, which necessitated additional time for milk FA to return to normal before the start of the subsequent experiment.

\section{RESULTS}

\section{Milk FA}

Cows fed WPEG had increases in proportions of C18:2 and C18:3 $(P<0.01)$ in all experiments during wk 2 vs. wk 1. Fatty acid C18:2 increased to 5.88, 7.42, and $6.56 \%$ during wk 2 compared with $3.17,3.24$, and $3.91 \%$ during wk 1 for Experiments 1, 2, and 3, respectively. Proportions of C18:3 increased during wk 2 from 0.55 to $0.84 \%$ for Experiment 1, 0.54 to $1.15 \%$ for Experiment 2, and 0.61 to $0.97 \%$ for Experiment 3. During Experiments 1 and 3, WPEG cows also had higher proportions of $\mathrm{C} 18: 1$ trans-11 in milk fat in wk $2(P<0.01)$ relative to wk 1. The proportion of C18:1 trans-11 increased markedly from 0.87 to $1.01 \%$ for Experiment 1 and 0.94 to $1.01 \%$ for Experiment 3.

Similarly, control cows in all experiments had an increase in $\mathrm{C} 18: 1$ trans-11 $(P<0.01)$ during wk 2 relative to wk 1. Proportion of C18:1 trans-11 increased from 0.89 to $1.27 \%$ in Experiment 1 (Table 4), 0.84 to $1.14 \%$ for Experiment 2 (Table 5), and 0.94 to $1.01 \%$ for Experiment 3 (Table 6). Control cows in Experiment 1 had a decreased proportion of C18:3 (from 0.57 to $0.51 \%)$ in milk fat during wk 2 relative to wk 1 ( $P<$ 0.01). Control cows in Experiments 2 and 3 exhibited no significant changes in milk fat C18:3. In Experiment 2, control cows had decreased proportions of C18:2 during wk 2 relative to wk 1 (2.91 vs. $3.08 \%$, respectively; $P<0.01$ ).

During wk 2, the C18:2 and C18:3 contents of milk fat for WPEG cows was higher than for controls for all experiments $(P<0.01)$, indicating protection of a portion of the FA contained in soybean oil (Tables 4 to 6). The C18:2 proportion for WPEG cows was 5.88, 7.42, and $6.56 \%$ compared with $3.29,2.91$, and $3.57 \%$ for controls in Experiments 1, 2, and 3, respectively. Likewise, the proportion of C18:3 for WPEG vs. controls in Experiments 1, 2, and 3 was 0.84 vs. $0.51 \%, 1.15$ vs. $0.52 \%$, and 0.97 vs. $0.51 \%$. The increase in both C18:2 (Figure 1) and C18:3 (Figure 2) was rapid following initiation of WPEG feeding. Accordingly, the proportion of C18:1 trans-9 was lower for WPEG cows relative to controls $(P<0.03)$ during wk 2 (Figure 3$)$. The C18:1 trans-11 $(P<0.03)$ and $\mathrm{C} 18: 0(P<0.03)$ proportions 
Table 4. Fatty acids (FA) in milk fat of cows fed whey protein concentrate $80 \%$ CP (WPC80 soybean oil whey protein gel emulsion) and control cows during wk 2 of Experiment 1

\begin{tabular}{|c|c|c|c|c|}
\hline & Control & WPC80 & $P$-value & $\mathrm{SE}$ \\
\hline & \multicolumn{4}{|c|}{$-\mathrm{g} / 100 \mathrm{~g}$ of $\mathrm{FA}-$} \\
\hline $\mathrm{C} 4$ & 4.35 & 4.14 & 0.65 & 0.07 \\
\hline C6 & 2.32 & 2.30 & 0.94 & 0.03 \\
\hline $\mathrm{C} 8$ & 1.24 & 1.29 & 0.79 & 0.03 \\
\hline C9 & 0.02 & 0.02 & 0.98 & $<0.01$ \\
\hline $\mathrm{C} 10$ & 2.57 & 2.86 & 0.62 & 0.08 \\
\hline C11 & 0.04 & 0.05 & 0.66 & $<0.01$ \\
\hline C12 & 2.79 & 3.12 & 0.63 & 0.09 \\
\hline C13 & 0.13 & 0.13 & 0.93 & $<0.01$ \\
\hline C14 & 10.08 & 10.16 & 0.93 & 0.13 \\
\hline $\mathrm{C} 14: 1 \mathrm{cis}$ & 0.77 & 0.54 & 0.02 & 0.02 \\
\hline C15 & 1.01 & 0.91 & 0.16 & 0.01 \\
\hline C16 & 28.52 & 27.67 & 0.05 & 0.09 \\
\hline $\mathrm{C} 16: 1$ trans & 0.44 & 0.35 & 0.04 & 0.01 \\
\hline $\mathrm{C} 16: 1 \mathrm{cis}$ & 1.12 & 1.04 & 0.66 & 0.03 \\
\hline C17 & 0.64 & 0.60 & 0.32 & 0.01 \\
\hline C18 & 16.39 & 15.84 & 0.75 & 0.25 \\
\hline C18:1 trans -9 & 0.38 & 0.28 & $<0.01$ & 0.01 \\
\hline C18:1 trans-11 & 1.27 & 1.01 & 0.03 & 0.02 \\
\hline C18:1 cis $-9 \& 10$ & 21.71 & 20.64 & 0.59 & 0.28 \\
\hline C18:2 & 3.29 & 5.88 & $<0.01$ & 0.18 \\
\hline C18:3 & 0.51 & 0.84 & $<0.01$ & 0.02 \\
\hline C18:2 cis-9 trans- 11 & 0.41 & 0.34 & 0.27 & 0.01 \\
\hline C18:1 trans -9 & 5.30 & 3.54 & 0.09 & 0.14 \\
\hline C18:1 trans -11 & 16.34 & 12.66 & 0.05 & 0.29 \\
\hline C18:2 & 44.96 & 74.51 & 0.01 & 1.77 \\
\hline C18:3 & 6.84 & 10.59 & 0.03 & 0.25 \\
\hline
\end{tabular}

were also lower in milk fat of WPEG cows compared with controls in Experiments 1 and 2, but not in Experiment 3 (Figure 4).

Transfer efficiency of C18:2 from oil to milk fat was 16.3, 30.1, and $28.2 \%$ for Experiments 1, 2, and 3, respectively. Efficiency of C18:3 transfer was 16.2, 33.2, $33.9 \%$ for Experiments 1, 2, and 3, respectively.

\section{Plasma FA}

Plasma concentration of C18:2 was markedly $(P<$ 0.01 ) higher for WPEG cows compared with controls in Experiments 1 and 2 (Table 7), further suggesting that a portion of the unsaturated FA was protected from rumen biohydrogenation in the WPEG complexes. In Experiment 2, plasma C18:0, C18:1 trans-9, and C18:1 trans-11 were lower $(P \leq 0.05)$ in WPEG cows compared with control cows. There were no differences in plasma FA concentrations during Experiment 3, as there was more variation.

\section{Animal Performance}

There were no evident palatability problems with the WPEG products. No differences in intake were observed
Table 5. Fatty acids (FA) in milk fat of cows fed whey protein isolate (WPI soybean oil whey protein gel emulsion) and control cows during wk 2 of Experiment 2

\begin{tabular}{|c|c|c|c|c|}
\hline & Control & WPI & $P$-value & $\mathrm{SE}$ \\
\hline & \multicolumn{4}{|c|}{$-\mathrm{g} / 100 \mathrm{~g}$ of $\mathrm{FA}-$} \\
\hline $\mathrm{C} 4$ & 4.14 & 4.11 & 0.95 & 0.08 \\
\hline $\mathrm{C} 6$ & 2.27 & 2.33 & 0.82 & 0.04 \\
\hline $\mathrm{C} 8$ & 1.24 & 1.27 & 0.88 & 0.02 \\
\hline C9 & 0.02 & 0.02 & 0.87 & $<0.01$ \\
\hline C10 & 2.77 & 2.71 & 0.89 & 0.06 \\
\hline C11 & 0.06 & 0.05 & 0.33 & 0.01 \\
\hline $\mathrm{C} 12$ & 3.10 & 2.91 & 0.72 & 0.07 \\
\hline C13 & 0.14 & 0.13 & 0.76 & $<0.01$ \\
\hline $\mathrm{C} 14$ & 10.86 & 9.89 & 0.17 & 0.13 \\
\hline $\mathrm{C} 14: 1$ cis & 0.65 & 0.60 & 0.52 & 0.01 \\
\hline C15 & 1.03 & 0.99 & 0.69 & 0.01 \\
\hline $\mathrm{C} 16$ & 29.53 & 27.49 & $<0.01$ & 0.17 \\
\hline $\mathrm{C} 16: 1$ trans & 0.43 & 0.39 & 0.21 & 0.01 \\
\hline $\mathrm{C} 16: 1 \mathrm{cis}$ & 1.18 & 0.91 & 0.36 & 0.04 \\
\hline C17 & 0.62 & 0.65 & 0.05 & 0.01 \\
\hline C18 & 15.78 & 15.35 & 0.72 & 0.17 \\
\hline C18:1 trans -9 & 0.36 & 0.26 & $<0.01$ & 0.01 \\
\hline C18:1 trans-11 & 1.14 & 0.95 & 0.03 & 0.02 \\
\hline C18:1 cis-9 \& 10 & 20.87 & 20.12 & 0.72 & 0.33 \\
\hline C18:2 & 2.91 & 7.42 & $<0.01$ & 0.31 \\
\hline C18:3 & 0.52 & 1.15 & $<0.01$ & 0.05 \\
\hline $\mathrm{C} 18: 2$ cis -9 trans -11 & 0.38 & 0.29 & 0.08 & 0.01 \\
\hline C18:1 trans -9 & 4.38 & 3.17 & 0.89 & 0.11 \\
\hline $\mathrm{C} 18: 1$ trans -11 & 13.83 & 11.51 & 0.30 & 0.30 \\
\hline C18:2 & 35.15 & 89.74 & 0.02 & 3.69 \\
\hline C18:3 & 6.27 & 13.95 & 0.04 & 0.56 \\
\hline
\end{tabular}

between WPEG and controls cows during treatment weeks (wk 2) of each experiment (Table 8).

There were no differences in the percentage and yield of milk fat, protein, lactose, and SNF production between WPEG and control cows in all experiments (Table 9). Milk production (kg/d) was numerically higher for control cows than for WPEG cows during Experiment 1, but higher in WPEG cows in Experiments 2 and 3. However, these results were not significant.

\section{DISCUSSION}

The design of our experiments involved the feeding of soybean oil in 3 distinct types of WPEG complex, compared with feeding the same amount of soybean oil in the TMR. Many published studies compared rumenprotected oil to a control diet with no added FA (Rotunno et al., 1998; Enjalbert et al., 2000), which makes comparison of milk FA, in particular the trans 18-carbon monoenes, difficult because the diets were not similar in chemical composition. In our study, feeding WPEG increased the unsaturated FA in milk fat similarly to previous reports in cattle (Cook et al., 1972; Gulati et al., 2002; Lundy et al., 2004) and sheep (Rotunno et al., 1998) fed rumen-protected unsaturated lipids. In one study, it was found that canola oil infused 
Table 6. Fatty acids (FA) in milk fat of cows fed whey protein concentrate high gel (WPCHG soybean oil whey protein gel emulsion) complex and control cows during wk 2 of Experiment 3

\begin{tabular}{lrrrr}
\hline & Control & WPCHG & $P$-value & \multicolumn{1}{c}{ SE } \\
\hline \multicolumn{4}{c}{ g/100 g of FA -} \\
C4 & 4.98 & 4.92 & 0.98 & 0.13 \\
C6 & 2.32 & 2.59 & 0.47 & 0.05 \\
C8 & 1.17 & 1.41 & 0.25 & 0.03 \\
C9 & 0.01 & 0.03 & 0.11 & $<0.01$ \\
C10 & 2.45 & 3.06 & 0.20 & 0.07 \\
C11 & 0.05 & 0.06 & 0.09 & $<0.01$ \\
C13 & 2.67 & 3.28 & 0.18 & 0.07 \\
C14 & 0.12 & 0.15 & 0.16 & $<0.01$ \\
C14:1 cis & 9.98 & 10.54 & 0.42 & 0.11 \\
C15 & 0.69 & 0.65 & 0.65 & 0.02 \\
C16 & 1.00 & 0.99 & 0.94 & 0.01 \\
C16:1 trans & 28.72 & 27.51 & 0.29 & 0.17 \\
C16:1 cis & 0.46 & 0.40 & 0.17 & 0.01 \\
C17 & 1.08 & 0.79 & 0.30 & 0.04 \\
C18 & 0.67 & 0.66 & 0.44 & $<0.01$ \\
C18:1 trans-9 & 15.46 & 14.91 & 0.71 & 0.23 \\
C18:1 trans-11 & 0.33 & 0.27 & 0.03 & 0.01 \\
C18:1 cis-9 \& 10 & 1.22 & 1.01 & 0.17 & 0.02 \\
C18:2 & 22.13 & 18.95 & 0.42 & 0.58 \\
C18:3 & 3.57 & 6.56 & $<0.01$ & 0.21 \\
C18:2 cis-9 trans-11 & 0.51 & 0.97 & $<0.01$ & 0.03 \\
& 0.42 & 0.32 & 0.06 & 0.01 \\
C18:1 trans-9 & & & & \\
C18:1 trans-11 & 5.58 & 4.57 & 0.62 & 0.12 \\
C18:2 & 20.80 & 17.20 & 0.69 & 0.35 \\
C18:3 & 60.98 & 112.13 & 0.77 & 3.09 \\
\hline & 8.78 & 16.60 & 0.93 & 0.46 \\
\cline { 2 - 3 } & & & &
\end{tabular}

directly into the rumen or added unprotected to the diet of dairy cattle increased proportions of C18:0, C18:1 trans-9, and C18:1 trans-11 of milk fat, whereas infusing the same oil directly into the abomasum increased proportions of C18:2 and C18:3 in milk fat (DePeters et al., 2001). Use of the WPEG products resulted in a similar effect on milk FA composition as did this infusion of canola oil directly into the abomasum, in that a large proportion of unsaturated long-chain FA was mostly unaffected by rumen modification.

The increase in unsaturated FA of milk fat by feeding WPEG of soybean oil in the present experiments was greater than observed for calcium salts of soybean oil, in which there was a small but significant increase in C18:2 (3.32 vs. $2.91 \mathrm{~g} / 100 \mathrm{~g}$ of FA) for calcium salts of soybean oil vs. calcium salts of palm FA distillate (Mandebvu et al., 2003). Likewise, in a separate study (Lundy et al., 2004) when calcium salts or amides of soybean oil were fed compared with soybean oil, milk composition of C18:2 changed little. Thus, feeding unsaturated FA in the form of calcium salts or amides appears to yield only a small decrease in rumen biohydrogenation of C18:2.

Concentration of milk oleic acid (C18:1 cis-9) did not change significantly when WPEG was fed to dairy cows in our study, although this FA is present in high concen-
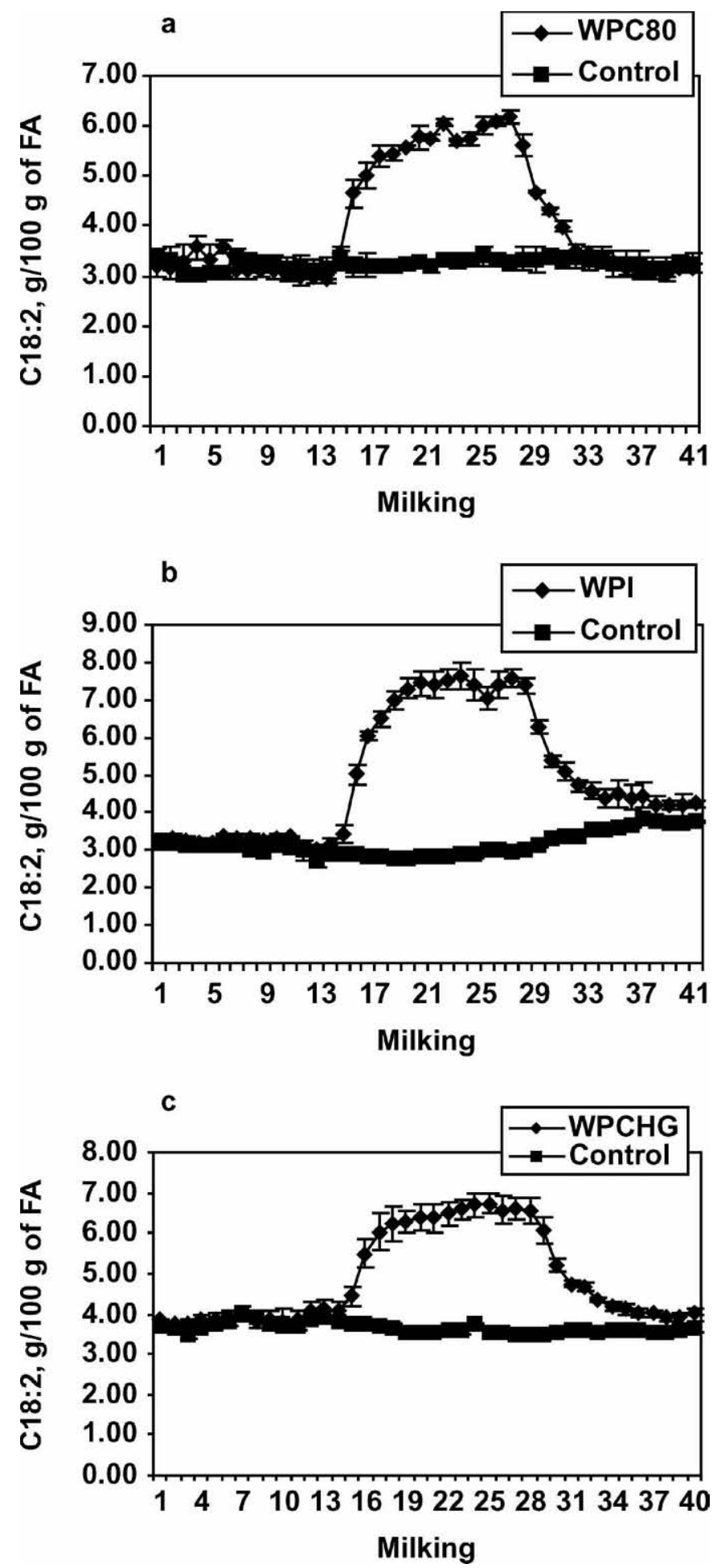

Figure 1. Average milk fatty acid (FA) proportions of C18:2 in Experiments 1 (a), 2 (b), and 3 (c). Feeding of whey protein emulsion gel began at milking 15 and ended at milking 29. Bars represent \pm SE; WPC80 = Whey protein concentrate ( $80 \%$ protein); WPI $=$ whey protein isolate; $\mathrm{WPCHG}=$ high gel whey protein concentrate $(80 \%$ protein). 

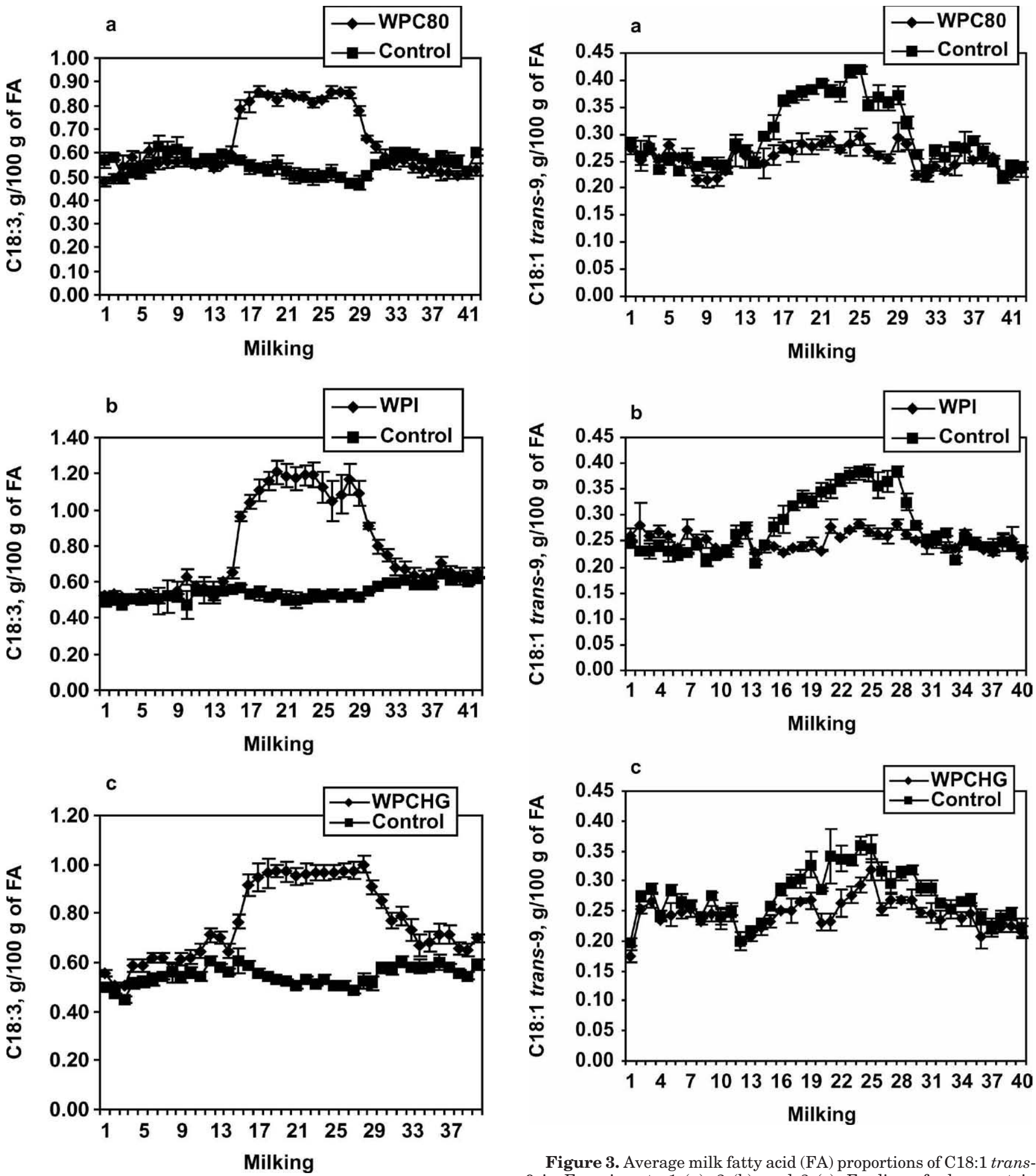

Figure 3. Average milk fatty acid (FA) proportions of C18:1 trans9 in Experiments 1 (a), 2 (b), and 3 (c). Feeding of whey protein emulsion gel began at milking 15 and ended at milking 29. Bars represent $\pm \mathrm{SE}$; WPC80 $=$ Whey protein concentrate $(80 \%$ protein $)$; $\mathrm{WPI}=$ whey protein isolate $\mathrm{WPCHG}=$ high gel whey protein concenExperiments 1 (a), 2 (b), and 3 (c). Feeding of whey protein emulsion gel began at milking 15 and ended at milking 29. Bars represent \pm $\mathrm{SE}$; WPC80 $=$ Whey protein concentrate $(80 \%$ protein $)$; $\mathrm{WPI}=$ whey trate $(80 \%$ protein). protein). 

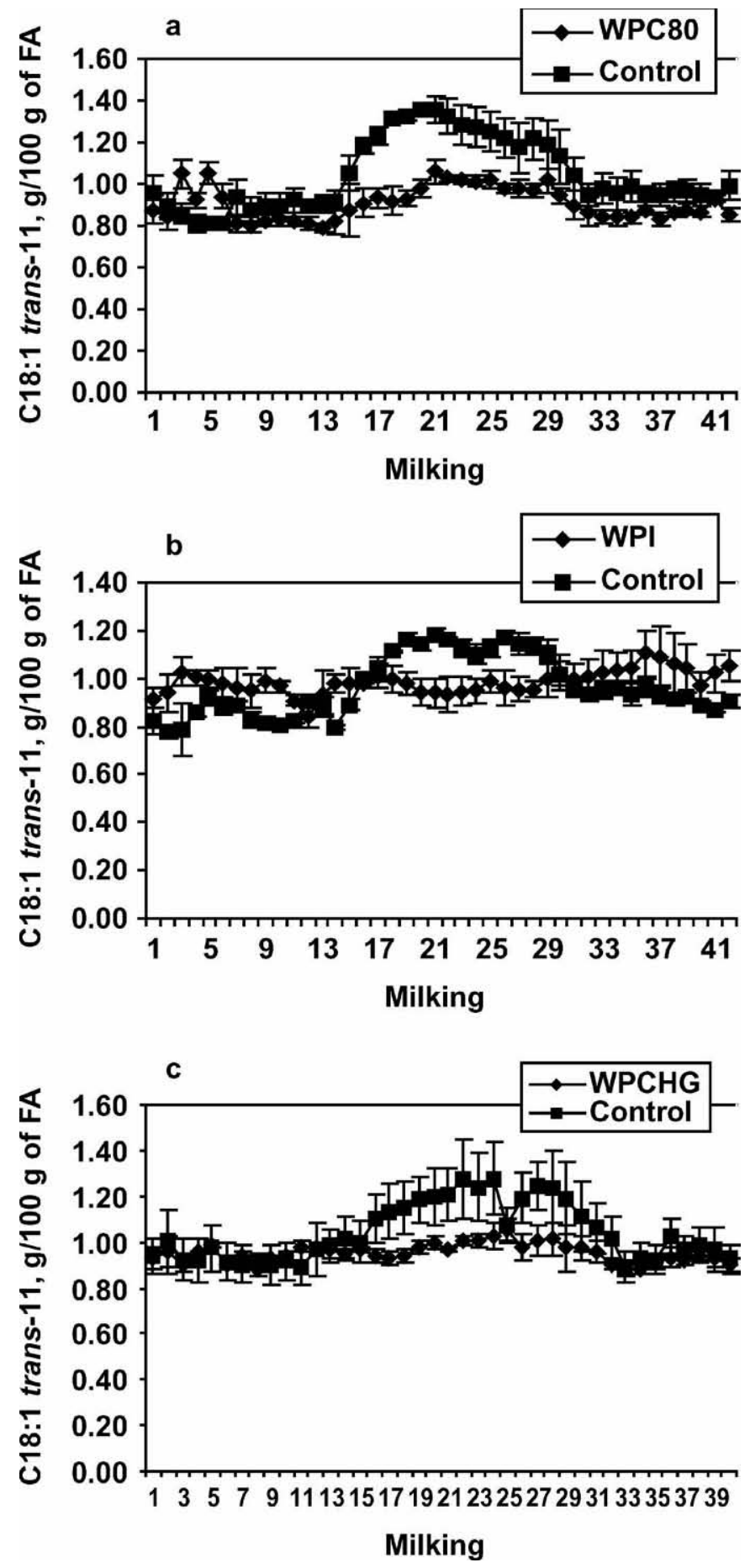

Figure 4. Average milk fatty acid (FA) proportions of C18:1 trans11 in Experiments 1 (a), 2 (b), and 3 (c). Feeding of whey protein emulsion gel began at milking 15 and ended at milking 29. Bars represent \pm SE; WPC $80=$ Whey protein concentrate $(80 \%$ protein $)$; $\mathrm{WPI}=$ whey protein isolate WPCHG = high gel whey protein concentrate $(80 \%$ protein).
Table 7. Fatty acids (g/100 g of fatty acids) in the triacylglycerol fraction of blood plasma of cows fed different formulations of whey protein emulsion gel (WPEG) and control cows on d 12 of each experiment $^{1}$

\begin{tabular}{|c|c|c|c|c|}
\hline & Control & WPEG & $P$-value & SE \\
\hline \multicolumn{5}{|c|}{ Experiment 1 (WPC80 gel) } \\
\hline C14 & 2.19 & 1.65 & 0.03 & 0.14 \\
\hline $\mathrm{C} 15$ & 1.51 & 1.23 & 0.02 & 0.07 \\
\hline C16 & 30.03 & 27.79 & 0.05 & 0.62 \\
\hline $\mathrm{C} 16: 1$ trans & 0.49 & 0.47 & 0.77 & 0.03 \\
\hline $\mathrm{C} 16: 1 \mathrm{cis}$ & 2.74 & 1.70 & 0.07 & 0.30 \\
\hline C17 & 1.39 & 1.30 & 0.32 & 0.04 \\
\hline C18 & 48.71 & 49.68 & 0.56 & 0.72 \\
\hline C18:1 trans -9 & 0.46 & 0.36 & 0.04 & 0.03 \\
\hline $\mathrm{C} 18: 1$ trans -11 & 2.10 & 1.82 & 0.45 & 0.16 \\
\hline $\mathrm{C} 18: 1$ cis $-9 \& 10$ & 6.02 & 6.99 & 0.32 & 0.44 \\
\hline C18:2 & 3.45 & 6.13 & $<0.01$ & 0.62 \\
\hline C18:3 & 0.35 & 0.47 & 0.14 & 0.04 \\
\hline C20:4 & 0.38 & 0.30 & 0.52 & 0.06 \\
\hline $\mathrm{C} 20: 5$ & 0.18 & 0.10 & 0.15 & 0.03 \\
\hline \multicolumn{5}{|c|}{ Experiment 2 (WPI gel) } \\
\hline C14 & 0.90 & 0.92 & 0.86 & 0.05 \\
\hline C15 & 1.13 & 1.00 & 0.40 & 0.07 \\
\hline C16 & 25.48 & 24.54 & 0.19 & 0.34 \\
\hline $\mathrm{C} 16: 1$ trans & 0.47 & 0.45 & 0.76 & 0.03 \\
\hline $\mathrm{C} 16: 1 \mathrm{cis}$ & 2.38 & 3.83 & 0.26 & 0.59 \\
\hline C17 & 1.62 & 1.84 & 0.02 & 0.06 \\
\hline C18 & 56.90 & 51.11 & 0.01 & 1.42 \\
\hline C18:1 trans -9 & 0.44 & 0.29 & 0.05 & 0.04 \\
\hline C18:1 trans -11 & 2.01 & 1.37 & $<0.01$ & 0.15 \\
\hline C18:1 cis-9\&10 & 6.01 & 7.97 & 0.03 & 0.52 \\
\hline $\mathrm{C} 18: 2$ & 2.23 & 6.03 & $<0.01$ & 0.88 \\
\hline C18:3 & 0.25 & 0.44 & 0.06 & 0.05 \\
\hline C20:4 & 0.15 & 0.16 & 0.84 & 0.03 \\
\hline $\mathrm{C} 20: 5$ & 0.02 & 0.04 & 0.64 & 0.02 \\
\hline \multicolumn{5}{|c|}{ Experiment 3 (WPCHG gel) } \\
\hline C14 & 1.57 & 1.50 & 0.60 & 0.06 \\
\hline C15 & 1.27 & 1.21 & 0.55 & 0.04 \\
\hline C16 & 26.65 & 26.93 & 0.79 & 0.46 \\
\hline C16:1 trans & 0.47 & 0.48 & 0.96 & 0.03 \\
\hline $\mathrm{C} 16: 1$ cis & 4.38 & 5.83 & 0.50 & 0.93 \\
\hline C17 & 1.88 & 1.86 & 0.96 & 0.15 \\
\hline C18 & 49.96 & 47.01 & 0.48 & 1.83 \\
\hline C18:1 trans -9 & 0.28 & 0.43 & 0.28 & 0.06 \\
\hline C18:1 trans -11 & 1.77 & 1.80 & 0.93 & 0.15 \\
\hline C18:1 cis-9\&10 & 7.10 & 6.98 & 0.93 & 0.56 \\
\hline C18:2 & 4.10 & 5.31 & 0.49 & 0.75 \\
\hline C18:3 & 0.35 & 0.50 & 0.21 & 0.06 \\
\hline C20:4 & 0.18 & 0.18 & 0.98 & 0.03 \\
\hline C20:5 & 0.05 & 0.00 & 0.37 & 0.02 \\
\hline
\end{tabular}

${ }^{1} \mathrm{WPC} 80=$ Whey protein concentrate $(80 \%$ protein $)$, Experiment 1 ; $\mathrm{WPI}=$ whey protein isolate, Experiment $2 ; \mathrm{WPCHG}=$ high gel whey protein concentrate (80\% protein), Experiment 3.

trations in soybean oil. This FA may have been incorporated for use into other tissues. Mashek et al. (2002) found that C18:1 yielded relatively high rates of incorporation into cellular lipids, whereas PUFA, including C18:2 and C18:3, were poor substrates.

Transfer efficiencies of C18:2 in Experiments 2 and 3 compare favorably with those published previously (Palmquist and Mattos, 1978; Drackley et al., 1992). Palmquist and Mattos (1978) reported a transfer rate of 47\% for labeled C18:2 infused postruminally. Addi- 
Table 8. Feed intake (kg/d) of cows fed different formulations of whey protein emulsion gel (WPEG) and control cows during wk 2 of each experiment $^{1}$

\begin{tabular}{lrrrr}
\hline & Control & WPEG & $P$-value & SE \\
\hline Experiment 1 (WPC80 gel) & & & & \\
DM & 22.12 & 21.26 & 0.49 & 0.54 \\
OM & 20.53 & 19.74 & 0.49 & 0.49 \\
NDF & 7.99 & 7.66 & 0.53 & 0.23 \\
CP & 3.74 & 3.74 & 0.60 & 0.02 \\
Ash & 1.59 & 1.52 & 0.46 & 0.05 \\
Experiment 2 (WPI gel) & & & & \\
DM & 21.89 & 21.30 & 0.74 & 0.77 \\
OM & 20.05 & 19.52 & 0.75 & 0.70 \\
NDF & 7.76 & 7.31 & 0.58 & 0.35 \\
CP & 3.77 & 3.77 & 0.75 & 0.02 \\
Ash & 1.85 & 1.78 & 0.65 & 0.06 \\
Experiment 3 (WPCHG gel) & & & & \\
DM & 27.36 & 27.82 & 0.91 & 0.95 \\
OM & 25.00 & 25.42 & 0.91 & 0.14 \\
NDF & 9.47 & 9.71 & 0.88 & 0.28 \\
CP & 5.28 & 5.28 & 0.88 & 0.05 \\
Ash & 2.36 & 2.39 & 0.92 & 0.05 \\
\hline
\end{tabular}

${ }^{1} \mathrm{WPC} 80=$ Whey protein concentrate $(80 \%$ protein $)$, Experiment 1 ; $\mathrm{WPI}=$ whey protein isolate, Experiment $2 ; \mathrm{WPCHG}=$ high gel whey protein concentrate (80\% protein), Experiment 3.

Table 9. Milk, fat, protein, lactose, and SNF production of cows fed different formulations of whey protein emulsion gel (WPEG) and control cows during wk 2 of each experiment ${ }^{1}$

\begin{tabular}{|c|c|c|c|c|}
\hline & Control & WPEG & $P$-value & $\mathrm{SE}$ \\
\hline \multicolumn{5}{|c|}{ Experiment 1 (WPC80 gel) } \\
\hline Milk (kg/d) & 35.07 & 29.64 & 0.30 & 2.36 \\
\hline Fat $(\%)$ & 3.73 & 4.05 & 0.33 & 0.15 \\
\hline Fat $(\mathrm{kg} / \mathrm{d})$ & 1.33 & 1.19 & 0.58 & 0.10 \\
\hline Protein (\%) & 2.99 & 3.33 & 0.14 & 0.11 \\
\hline Protein $(\mathrm{kg} / \mathrm{d})$ & 1.05 & 0.98 & 0.65 & 0.06 \\
\hline Lactose $(\%)$ & 4.69 & 4.88 & 0.41 & 0.10 \\
\hline Lactose $(\mathrm{kg} / \mathrm{d})$ & 1.66 & 1.45 & 0.49 & 0.13 \\
\hline SNF $(\%)$ & 8.65 & 8.96 & 0.17 & 0.11 \\
\hline $\mathrm{SNF}(\mathrm{kg} / \mathrm{d})$ & 3.05 & 2.65 & 0.42 & 0.21 \\
\hline \multicolumn{5}{|c|}{ Experiment 2 (WPI gel) } \\
\hline Milk (kg/d) & 28.32 & 31.72 & 0.55 & 2.44 \\
\hline Fat $(\%)$ & 3.84 & 3.79 & 0.85 & 0.11 \\
\hline Fat (kg/d) & 1.08 & 1.21 & 0.56 & 0.09 \\
\hline Protein (\%) & 3.30 & 3.04 & 0.14 & 0.09 \\
\hline Protein $(\mathrm{kg} / \mathrm{d})$ & 0.93 & 0.96 & 0.79 & 0.06 \\
\hline Lactose $(\%)$ & 4.78 & 4.82 & 0.87 & 0.09 \\
\hline Lactose (kg/d) & 1.36 & 1.54 & 0.57 & 0.14 \\
\hline $\mathrm{SNF}(\%)$ & 8.86 & 8.75 & 0.56 & 0.08 \\
\hline $\mathrm{SNF}(\mathrm{kg} / \mathrm{d})$ & 2.51 & 2.78 & 0.58 & 0.21 \\
\hline \multicolumn{5}{|c|}{ Experiment 3 (WPCHG gel) } \\
\hline Milk (kg/d) & 41.33 & 46.31 & 0.61 & 4.16 \\
\hline Fat $(\%)$ & 3.57 & 3.68 & 0.47 & 0.06 \\
\hline Fat (kg/d) & 1.46 & 1.71 & 0.44 & 0.14 \\
\hline Protein (\%) & 3.06 & 3.15 & 0.55 & 0.07 \\
\hline Protein $(\mathrm{kg} / \mathrm{d})$ & 1.26 & 1.46 & 0.52 & 0.13 \\
\hline Lactose $(\%)$ & 4.70 & 4.87 & 0.21 & 0.06 \\
\hline Lactose $(\mathrm{kg} / \mathrm{d})$ & 1.94 & 2.25 & 0.50 & 0.20 \\
\hline $\operatorname{SNF}(\%)$ & 8.67 & 8.83 & 0.37 & 0.08 \\
\hline $\mathrm{SNF}(\mathrm{kg} / \mathrm{d})$ & 3.58 & 4.09 & 0.55 & 0.37 \\
\hline
\end{tabular}

${ }^{1} \mathrm{WPC} 80=$ Whey protein concentrate ( $80 \%$ protein), Experiment $1 ;$ $\mathrm{WPI}=$ whey protein isolate, Experiment 2; WPCHG = high gel whey protein concentrate (80\% protein), Experiment 3. tionally, assuming $47 \%$ as the transfer rate of thoroughly protected C18:2, transfer efficiencies of C18:2 in this study can also be expressed by comparison with abomasal infusion as $100 \%$ protection (De Veth et al., 2005). Using this method, transfer efficiencies for C18:2 are 34.7, 64.0, and $60.0 \%$ in Experiments 1, 2, and 3 , respectively.

Trans-11 C18:1 is an intermediate in the rumen biohydrogenation of C18:2 (Harfoot,1978). The lower proportion of trans-11 C18:1 in milk fat of cows fed WPC80 (Figure 4a) and WPI (Figure 4b) compared with controls supports protection of soybean oil by the WPEG complex, although some biohydrogenation of FA in the WPEG did occur. For example, in WPC80 there was a slight increase in partially hydrogenated 18-carbon FA (Table 4). Although the proportion of trans-9 C18:1 in milk fat decreased, the proportion of trans-11 C18:1 was not different between WPCHG and controls (Figure 3c; Experiment 3). Some biohydrogenation of FA did occur in WPCHG, because a slight increase in partially hydrogenated 18-carbon FA was observed.

Feeding WPEG to lactating cows had no effect on feed intake (Table 8). However, feeding WPEG had slight, but not significant, effects on milk yield and composition due to large standard error (Table 9). This could be attributed to individual differences in parity and milk production between cows. Milk yield averages per cow ranged from 22 to $55 \mathrm{~kg} / \mathrm{d}$ throughout the 3 experiments.

Our experiments were relatively short (7-d treatment periods) due to the lack of large-scale manufacturing equipment. Further study is required to determine the effects of prolonged feeding of the WPEG on milk FA production. Wrenn et al. (1975) reported a steady and significant increase in milk C18:2 in response to feeding a formaldehyde-treated soybean and sunflower seed mixture in amounts that were doubled weekly for $8 \mathrm{wk}$. Another study, in which formaldehyde-treated safflower oil-casein was fed to dairy cows for 2 lactations, reported that the high C18:2 concentration in milk gradually declined, but remained steady at $26 \mathrm{wk}$ (Wrenn et al., 1976). However, milk C18:2 after this decline was still significantly higher than that of the control (7.5 vs. $4.5 \%)$.

In humans, saturated fatty acids have been associated with low-density lipoprotein cholesterol levels and risk of developing cardiovascular disease (Clarke et al., 1997; Yu-Poth et al., 1999; Lichtenstein, 2003). Replacement of dietary saturated FA by monounsaturated and PUFA leads to a modest decrease in low-density lipoprotein cholesterol levels (Lichtenstein, 2003). Therefore, increasing the proportion of PUFA in milk may be beneficial for cardiovascular health. 
Taken together, the increase in C18:2 and C18:3, and the lack of change (for the most part) in trans-11 C18:1 with feeding of WPEG complexes indicate protection of unsaturated FA from rumen biohydrogenation and subsequent absorption of these unsaturated FA in the small intestine for eventual incorporation into milk fat. This study examined only triacylglycerol FA, not the other lipid classes (e.g., phospholipid FA). Previous research has shown that proportions of some FA (C18:2, C18:3, C20:4) are higher in milk phospholipids than in milk triacylglycerols (Prieto et al., 2003; McCaughey et al., 2005). If this study had looked at milk phospholipids, it is probable that FA transfer efficiencies would have been higher than observed. Future research will look at changes in both triacylglycerol and phospholipid milk fractions that occur after feeding WPEG.

\section{CONCLUSIONS}

When WPEG was added to the diet of lactating cows, it successfully protected a portion of the unsaturated FA in soybean oil and dramatically increased the C18:2 and C18:3 content of milk fat without significantly increasing the trans 18-carbon monoenes. The increase in n-3 FA composition may have human health implications because n-3 FA have been linked to a reduced risk of coronary heart disease. Using WPEG to modify the FA composition of milk fat for human health could reposition milk fat in a healthy human diet.

\section{ACKNOWLEDGMENTS}

The authors express their sincere appreciation to Scott Taylor for the milk analyses, Jennifer Pareas for project oversight, Fred Stewart and Walter Paroczai for milk sample collection, and Fred Sauers, Douglas Gisi, and Sharlie Cunningham for preparation of the diet. Additional thanks are due to Natalie Tankersley, Joanna Holtz, Elizabeth Abell, and Isabelle Curtis for their assistance with feeding and laboratory analysis.

\section{REFERENCES}

AOAC. 1990. Official Methods of Analysis. 15th ed. Association of Official Analytical Chemists, Arlington, VA.

Ashes, J. R., S. K. Gulati, E. F. Kitessa, and T. W. Scott. 2000. Utilisation of rumen-protected n-3 fatty acids by ruminants. Pages 129-140 in Recent Advances in Animal Nutrition. P. C. Garnsworthy and J. Wiseman, ed. Nottingham Univ. Press, Nottingham, UK.

Ashes, J. R., S. K. Gulati, and T. W. Scott. 1997. Symposium: New approaches to changing milk composition. Potential to alter the content and composition of milk fat through nutrition. J. Dairy Sci. 80:2204-2212.

Barker, M. E. 2000. Impact of consumption of milk and milk products on human health. Pages 19-28 in Milk Composition. R. A. Agnew, A. M. Fearon, ed. Br. Soc. Anim. Sci., Edinburgh, UK.
Chen, J., and E. Dickinson. 1999. Interfacial aging effect on the rheology of a heat-set protein emulsion gel. Food Hydrocoll. 13:363-369.

Clarke, R., C. Frost, R. Collins, P. Appleby, and R. Peto. 1997. Dietary lipids and blood cholesterol: Quantitative meta-analysis of metabolic ward studies. Br. Med. J. 314:112-117.

Cook, L. J., T. W. Scott, and Y. S. Pan. 1972. Formaldehyde treated casein-safflower oil supplement for dairy cows II: Effect on fatty acid composition of plasma and milk lipids. J. Dairy Res. 39:211-218.

Creamer, L. K., L. E. Pearce, J. P. Hill, and M. J. Boland. 2002. Milk and dairy products in the 21st century. J. Agric. Food Chem. 50:7187-7193.

Crocker, L. M., E. J. DePeters, J. G. Fadel, J. Perez-Monti, S. J. Taylor, J. A. Wyckoff, and R. A. Zinn. 1998. Influence of processed corn grain in diets of dairy cows on digestion of nutrients and milk composition. J. Dairy Sci. 84:929-936.

DePeters, E. J., J. B. German, S. J. Taylor, S. T. Essex, and H. PerezMonti. 2001. Fatty acid and triglyceride composition of milk fat from lactating Holstein cows in response to supplemental canola oil. J. Dairy Sci. 84:929-936.

De Veth, M. J., S. K. Gulati, N. D. Luchini, and D. E. Bauman. 2005. Comparison of calcium salts and formaldehyde-protected conjugated linoleic acid in inducing milk fat depression. J. Dairy Sci. 88:1685-1693.

Drackley, J. K., T. H. Klusmeyer, A. M. Trusk, and J. H. Clark. 1992. Infusion of long-chain fatty acids varying in saturation and chain length into the abomasum of lactating dairy cows. J. Dairy Sci. 75:1517-1526.

Enjalbert, F., M. C. Nicot, C. Bayourthe, and R. Moncoulon. 2000. Effects of duodenal infusions of palmitic, stearic, or oleic acids on milk composition and physical properties of butter. J. Dairy Sci. 83:1428-1433.

German, J. B., L. Morand, C. J. Dillard, and X. Ruping. 1997. Milkfat composition: Targets for alteration of function and nutrition. Pages 35-72 in Milk composition, production and biotechnology. R. A. S. Welch, S. R. Davis, A. I. Popay, and C. G. Prosser, ed. CAB International, New York, NY.

Gezimati, J., H. Singh, and L. K. Creamer. 1996. Aggregation and gelation of bovine $\beta$-lactoglobulin, $\alpha$-lactalbumin and serum albumin. Pages 113-123 in Macromolecular interactions in food technology, ACS Symposium Series 650. N. Parris, A. Kato, L. K. Creamer, and J. Pearce, ed. American Chemical Society, Washington, DC.

Gregory, J., K. Foster, H. Tyler, and M. Wiseman. 1990. The Dietary and Nutritional Survey of British Adults. HMSO, London, UK.

Gulati, S. K., C. May, P. C. Wynn, and T. W. Scott. 2002. Milk fat enriched in n-3 fatty acids. Anim. Feed Sci. Technol. 98:143-152.

Harfoot, C. G. 1978. Lipid metabolism in the rumen. Prog. Lipid Res. $17: 21-54$.

Havel, R. J. 1997. Milk fat consumption and human health: Recent $\mathrm{NIH}$ and other American governmental recommendations. Milk composition, production and biotechnology. R. A. S. Welch, S. R. Davis, A. I. Popay, and C. G. Prosser, ed. CAB International, New York, NY.

Hodges, R. E., A. F. Salel, W. L. Dunkley, R. Zelis, P. F. McDonagh, C. Clifford, R. K. Hobbs, L. M. Smith, A. Fan, D. T. Mason, and C. Lykke. 1975. Plasma lipid changes in young adult couples consuming polyunsaturated meats and dairy products. Am. J. Clin. Nutr. 28:1126-1140.

Ikeda, S., K. Nishinari, and E. A. Foegeding. 2001. Mechanical characterization of network formation during heat-induced gelation of whey protein dispersions. Biopolymers 56:109-119.

Ingalls, S. T., Y. Xu, and C. L. Hoppel. 1995. Determination of plasma non-esterified fatty acids and triglyceride fatty acids by gas chromatography of their methyl esters after isolation by column chromatography on silica gel. J. Chromatogr. B 666:1-12.

Kromhout, D., A. Menhotti, H. Kestleloot, and S. Sans. 2002. Prevention of coronary heart disease by diet and lifestyle: Evidence from prospective cross-cultural, cohort, and intervention studies. Circulation 105:893-898. 
LaRosa, J. C., D. Hunninghake, D. Bush, M. H. Criqui, G. S. Getz, A. M. Gotto, Jr., S. M. Grundy, L. Rakita, R. M. Roberston, and M. L. Weisfeldt. 1990. The cholesterol facts: A summary of the evidence relating to dietary fats, serum cholesterol and coronary heart disease. A joint statement by the American Heart Association and the National Heart, Lung and Blood Institute. The task force on cholesterol issues, American Heart Association. Circulation 81:1721-1733.

Lichtenstein, A. H. 2003. Dietary fat and cardiovascular disease risk: Quantity or quality? J. Womens Health 12:109-114.

Lundy, F. P., E. Block, W. C. Bridges, Jr., J. A. Bertrand, and T. C. Jenkins. 2004. Ruminal biohydrogenation in Holstein cows fed soybean fatty acids as amides or calcium salts. J. Dairy Sci. 87:1038-1046.

Mandebvu, P., C.S. Ballard, C. J. Sniffen, M. P. Carter, H. M. Wolford, T. Sato, Y. Yabuuchi, E. Block, and D. L. Palmquist. 2003. Effect of feeding calcium salts of long-chain fatty acids, from palm fatty acid distillate or soybean oil, to high producing dairy cows on milk yield and composition, and on selected blood and reproductive parameters. Anim. Feed Sci. Technol. 108:25-41.

Mashek, D. G., S. J. Bertics, and R. R. Grummer. 2002. Metabolic fate of long-chain unsaturated fatty acids and their effects on palmitic acid metabolism and gluconeogenesis in bovine hepatocytes. J. Dairy Sci. 85:2283-2289.

McCaughey, K. M., E. J. DePeters, P. H. Robinson, J. E. P. Santos, S. J. Taylor, and J. W. Pareas. 2005. Impact of feeding whole Upland cottonseed, with or without cracked Pima cottonseed with increasing addition of iron sulfate, on milk and milk fat composition of lactating dairy cattle. Anim. Feed Sci. Technol. 123/ 124:667-685.

Morr, C. V., and E. Y. W. Ha. 1993. Whey protein concentrates and isolates: Processing and functional properties. Crit. Rev. Food Sci. 33:431-476.

Nakamura, M. T., A. B. Tang, J. Villanueva, C. H. Halsted, and S. D. Phinney. 1992. Reduced tissue arachidonic acid concentration with chronic ethanol feeding in miniature pigs. Am. J. Clin. Nutr. 56:467-474.

Noakes, M., P. J. Nestel, and P. M. Clifton. 1996. Modifying the fatty acid profile of dairy products through feedlot technology lowers the plasma cholesterol of humans consuming the products. Am. J. Clin. Nutr. 63:42-46.

Palmquist, D. L., and W. Mattos. 1978. Turnover of lipoproteins and transfer to milk fat of dietary (1-carbon-14) linoleic acid in lactating cows. J. Dairy Sci. 61:561-565.

Pan, Y. S., L. J. Cook, and T. W. Scott. 1972. Formaldehyde treated casein-safflower oil supplement for dairy cows I: Effect on milk composition. J. Dairy Res. 39:203-210.

Prieto, J. G., E. J. DePeters, P. H. Robinson, J. E. P. Santos, J. W. Pareas, and S. J. Taylor. 2003. Increasing dietary levels of cracked Pima cottonseed increase plasma gossypol but do not influence productive performance of lactating Holstein cows. J. Dairy Sci. 86:254-267.
Reh, W. A., E. A. Maga, N. M. B. Collette, A. Moyer, J. C. Brink, S. J. Taylor, E. J. DePeters, S. Oppenheim, J. D. Rowe, R. H. BonDurant, G. B. Anderson, and J. D. Murray. 2004. Hot Topic: Using a stearoyl-CoA desaturase transgene to alter milk fatty acid composition. J. Dairy Sci. 87:3510-3514.

Robertson, J. B., and P. J. Van Soest. 1981. The detergent system of analysis and its application to human foods. Pages 123-158 in The Analysis of Dietary Fiber in Foods. W. P. T. James, and O. Theander, ed. Marcel Dekker, New York, NT.

Rosenberg, M., and E. J. DePeters. 2004. Method and compositions for preparing and delivering rumen-protected lipids, other nutrients and medicaments. U.S. Patent Application 20040058003 A1 (Pending). The Regents of the University of California, Oakland, assignee.

Rosenberg, M., and E. J. DePeters. 2005. Method and compositions for delivering rumen protected-lipids, other nutrients and medicaments. U.S. Patent Application 20050089550 A1 (Pending). The Regents of the University of California, Oakland, assignee.

Rotunno, T., A. Sevi, D. Caterina, and A. Muscio. 1998. Effects of graded levels of dietary rumen-protected fat on milk characteristics of Comisana ewes. Small Rumin. Res. 30:137-145.

SAS Institute. 1985. SAS User's Guide: Statistics. SAS Institute, Inc., Cary, NC.

Scott, T. W., L. J. Cook, and S. C. Mills. 1971. Protection of dietary polyunsaturated fatty acids against microbial hydrogenation in ruminants. J. Am. Oil Chem. Soc. 48:358-364.

Sukhija, P. S., and D. L. Palmquist. 1990. Dissociation of calcium soaps of long chain fatty acids in rumen fluid. J. Dairy Sci. 73:1784-1787.

Tolstoguzov, V. 1996. Structure-property relationships in foods. Pages 3-14 in Macromolecular interactions in food technology, ACS Symposium Series 650. N. Parris, A. Kato, L. K. Creamer, and J. Pearce, ed. American Chemical Society, Washington, DC.

Van Soest, P. J., B. Robertson, and B. A. Lewis. 1991. Methods of dietary fiber, neutral detergent fiber, and nonstarch polysaccharides in relation to animal nutrition. J. Dairy Sci. 74:3583-3597.

Verheul, M., and S. P. F. M. Roefs. 1998a. Structure of particular whey protein gels: Effects of $\mathrm{NaCl}$ concentration, $\mathrm{pH}$, heating temperature, and protein composition. J. Agric. Food Chem. 46:4909-4916.

Verheul, M., and S. P. F. M. Roefs. 1998b. Structure of whey protein gels studied by permeability, scanning electron microscopy and rheology. Food Hydrocoll. 12:17-24.

Wrenn, T. R., J. Bitman, J. R. Weyant, and D. L. Wood. 1976. Milk and tissue lipid composition after feeding cows protected polyunsaturated fat for two years. J. Dairy Sci. 60:521-532.

Wrenn, T. R., J. R. Weyant, D. L. Wood, and J. Bitman. 1975. Increasing polyunsaturation of milk fats by feeding formaldehyde protected sunflower-soybean supplement. J. Dairy Sci. 59:627-635.

Yu-Poth, S., G. Zhao, T. Etherton, M. Naglak, S. Jonnalagadda, and P. M. Kris-Etherton. 1999. Effects of the National Cholesterol Education Program's Step I and Step II dietary intervention programs on cardiovascular disease risk factors: A meta-analysis. Am. J. Clin. Nutr. 69:632-646. 